\title{
INTERNAL EVALUATION IN BIOCHEMISTRY DEPARTMENT, MEDICINE FACULTY, TEHRAN UNIVERSITY OF MEDICAL SCIENCES
}

\author{
${ }^{1}$ Fereshteh Farzianpour, ${ }^{2}$ Mohamad Ansari and ${ }^{3}$ Shadi Hosseini \\ ${ }^{1}$ Department of Health Management and Economics, \\ School of Public Health, Tehran University of Medical Sciences, Tehran, Iran \\ ${ }^{2}$ Departments of Biochemistry, Medicine Faculty, Tehran University of Medical Sciences, Tehran, Iran \\ ${ }^{3}$ Department of Management, University of Tehran Kish International Campuse, Iran
}

Received 2014-07-27; Revised 2014-12-18; Accepted 2014-12-19

\begin{abstract}
Evaluation is a systematic process for collecting, analyzing and interpretation of the obtained information for the purpose of investigating how many the objectives in mind can be achieved. Education in an academic educational system means bringing about proper and increasing changes that affect the outcome of this system, that is affecting the students and the aim of such evaluation was promotion of the quality of an education process. In this study Biochemistry Department, Medicine Faculty Tehran University of Medical Sciences, benefiting from opinion poll of university lectures, student and graduates have evaluated their system of educational in the year 2004 and their aim was to remodel and adjust educational system with the society's needs and promotion of the quality of such educations. The employed method was cross sectional and descriptive and analytical on the basis of 10 procedural steps and within 8 sections dealing with evaluated factors. Such as faculty board members, management and organizational capability, students, manpower and logistic affairs, educational environments research work centers, health and therapeutic sections, educational equipment, research equipment, laboratory and diagnosis centers, educational courses and programs, teaching and learning process as well as satisfaction expressed by students. The results of the research showed that general average of 8 investigating sections, based on SWOTs model was \%58 that may well be interpreted as a desirable research work. Educational evaluation is the best indicator showing how much we should go to achieve certain aims, analyses quality of the activity if such a system and by which we achieve logical and routine results.
\end{abstract}

Keywords: Internal Evaluation, Biochemistry Department, Medicine Faculty, Tehran University of Medical Sciences

\section{INTRODUCTION}

Educational evaluation is the best indicator to the level of educational objectives achievement and it deals with analyze of educational activities in university system and from that it is possible to reach rational and well-known results (Farzianpour et al., 2014a).
Tehran University of Medical Sciences and Health Services, Iran, is considered as one of the most important, educational, health care and research institute in society for problems solutions and for training specialist and efficient forces (Farzianpour et al., 2014b).

It is expected that this educational institute will define a method for solving social intricate issues and for Corresponding Author:Fereshteh Farzianpour, Department of Health Management and Economics, School of Public Health, Tehran University of Medical Sciences, Tehran, Iran Tel: +98 2144658703 Fax: +98 2166462267 
development of the science by training potential learner's abilities (Farzianpour et al., 2014c), to meet expectations of the society, it is necessary to define objective and appropriate planning in order to reach these results, Planning in the university begins with understanding the needs. It leads to evaluate or process of compiling required data in order to judge a bout decision making issues in educational system for increasing quality level (Farzianpour et al., 2014d).

On the other hand, world is changing so rapidly and continually, that it is to be considered as a necessity to review educational programs continually for new expectations (Farzianpour et al., 2013a).

Appropriate evaluation and research in education are considered as practical tools for confirming to these changes in order to promote research, health care and educational quality levels (Farzianpour et al., 2009).

In this way, the success key and reaching the required, quality level in this university are training scientific board members and encourage them to participate in activities, evaluation of group activities solving of problems and making standard educational elements and tools (Farzianpour et al., 2010a; 2011a; 2012).

To this, in 2004, Study and Educational Development Center in Tehran University of Medical Sciences decided to perform an internal evaluation plan for Biochemistry group in Medicine Faculty, Tehran University of Medical Sciences. This plan was about their situation and existed abilities so they could identify strengths and weaknesses in order to compensate the shortages. Consequently they could declare their preparation to perform internal evaluation annually as well as external periodic evaluation, on the basis of compiled indicators and functional basis and eventually accreditation, validity measurements and validity recognizing at university level (Farzianpour et al., 2010b; 2010c).

\section{MATERIALS AND METHODS}

In this study, educational group of Biochemistry in Medicine Faculty, Tehran University of Medical Sciences evaluated using some questionnaires to scientific board members and students between 20012004 in order to conformity education to society needs and increasing quality level.

This study was cross sectional and survey descriptive and analytical evaluation questionnaires were some tools for collecting data which included collected statements and closed and opened type choices and multiple choice.

All statements of questionnaires were developed and standardized for validity and reliability based on the latest resources and educational evaluation sources (Farzianpour et al., 2011b).

The educational evaluation was performed based on the following 10 steps and in 8 areas (Table 1):

Table 1. Steps of internal evaluation and areas of evaluated

Step1: To acquaint scientific board members about evaluation educational management Process

Step2: To envelop committees on evaluation in educational and remedial courses and explain about it to members

Step3: To compile objectives (educational remedial and research objectives)

Step4: To define evaluation factors and related criterion.

Step5: To define and compile appropriate indicators for evaluation of factors.

Step6: To specify the required data for judging about each one of the factors.

Step7: To select and compile-needed tolls for collecting data.

Step8: To collect data

Step9: To analyze data, discussion and making conclusion.

Step10: To prepare a report and represent suggestion

\section{The areas under study were as follows:}

- $\quad$ Organization and management

- Scientific Board

- Learners

- Human resources and support

- Remedial hygienic research and educational spaces

- Diagnosis laboratories, research and educational equipment

- Educational programs and courses and learning-Teaching Process

- Satisfaction of the graduates 


\subsection{Validity of Data Collecting Tools}

A table was developed before preparation data collecting tools, which exactly specified each one of the related research questions and on that basis, the tools were provided. Then to define appropriate validity of date collecting tools, experts reviewed compiled questionnaires; next questions were clarified including direct questions and uncertainties. The main requirement to questionnaire validity was providing correct questionnaires with expressions whose uncertainties were minimized as much as possible. The content validity matter was that question sample scientific important aspect of the objective at research or not.

In order to obtain scientific validity for questionnaires, content validity method was used. The questions were provided through text study and present research collections (Farzianpour et al., 2011a). In concern to stability in data collecting tools about question was defined and clarified.

\subsection{Data Analysis Method}

Data description, abundant collections, preparing abundant tables, percentages, $\mathrm{X}^{2}$, regressions and variance analysis were used as follows:

- Fox pro program was used for inputting data to computer and editing them

- Data were analyzed using SPSS versions $9 \& 10$, we used descriptive and analytical statistics such as absolute frequency, arithmetic and geometric means, percentages, chi-squares, distribution and regression analysis

- For providing and designing graphs software HG-3 was used
- Data resulted from research was quantified by appropriate calculation formulations and then compared with each other. The resulted calculations were recorded in related tables to represent information. In order to compare data in each case ANOVA Test and $\mathrm{x} 2$ method were used

- On the basis of SWOTs pattern educational evaluation results in 15 groups on basic and clinical sciences were studied.

- Software SPSS and Excel were used to convert qualitative data to quantitative data

To identify strengths and weaknesses in areas under study which were as follows, the survey range in all educational groups was used:

Data results less than \%50 was undesirable; Data results between $\% 50-\% 75$ were relatively desirable; Data results more than $\% 75$ is desirable.

\section{RESULTS}

As shown in Table 2 and 3 educational evaluation council on educational group of Biochemistry in Medicine Faculty, Tehran University of Medical Sciences was developed educational strategies based on special objectives and educational indicators based on criteria.

Average results from educational evaluation at educational group were represented at (Fig. 1).

Strengths and weaknesses, opportunities and threats educational were analyzed on the basis of SWOTs pattern at the educational group (Table 4).

Table 2. Educational strategies based on special objectives

\begin{tabular}{ll}
\hline Special objectives & Educational strategies \\
\hline $\begin{array}{l}\text { 1-Improving and promotion of quality level and } \\
\text { remedial hygienic research and educational program } \\
\text { development conforming to society needs at university level. }\end{array}$ & 1- Internal evaluation about educational programs quality \\
$\begin{array}{l}\text { 2- Increasing the number of scientific board members } \\
\text { and specialists in educational groups. }\end{array}$ & $\begin{array}{l}\text { 2- Present permanent system reviews in order to performance } \\
\text { of desirable internal evaluation. }\end{array}$ \\
$\begin{array}{l}\text { 3- Knowledge development and achieving } \\
\text { modern technologies. }\end{array}$ & $\begin{array}{l}\text { 3- Developing scientific relations with other } \\
\text { universities and domestic and foreign authorized centers. }\end{array}$ \\
$\begin{array}{l}\text { 4-Training efficient human resources at remedial } \\
\text { hygienic research and educational courses. }\end{array}$ & 4- Promotion of short time educational courses qualitatively. \\
5-Promotion of scientific board members, facilities, \\
$\begin{array}{l}\text { equipment conditions and educational resources in } \\
\text { laboratories and so on in this purpose, strategies } \\
\text { were developed for above mentioned special objectives. }\end{array}$
\end{tabular}


Table 3. Indicators based on criteria

\begin{tabular}{|c|c|}
\hline Criteria & Indicators \\
\hline Management & $\begin{array}{l}\text { Management organizational structure, remedial research, service and educational } \\
\text { Performance function description, internal and external activities of members } \\
\text { planning, management authorities. }\end{array}$ \\
\hline Scientific board & $\begin{array}{l}\text { Scientific board distribution, operational, remedial, hygienic research and educational } \\
\text { activity information and experience. }\end{array}$ \\
\hline Learners & Educational improving. \\
\hline Learning teaching Process & $\begin{array}{l}\text { Applying educational technology by scientific board, } \\
\text { educational improving, teaching methods and graduates. }\end{array}$ \\
\hline $\begin{array}{l}\text { Educational courses and } \\
\text { curriculum }\end{array}$ & $\begin{array}{l}\text { Educational courses quality, conforming courses } \\
\text { to objectives, group courses content, conforming courses to mission, } \\
\text { objectives, facilities and program evaluation. }\end{array}$ \\
\hline Graduates & $\begin{array}{l}\text { Capability, identification, relation between learners and their educational } \\
\text { group after completing education, occupational future (destination) } \\
\text { keeping education, management and planning service receivers' } \\
\text { comments about learners occupation capabilities. }\end{array}$ \\
\hline Equipment & $\begin{array}{l}\text { Service remedial hygienic research and educational resources. } \\
\text { Space, facilities, laboratory, library, computer, visual and audio } \\
\text { Radiology, clinic, office and pavilion and... }\end{array}$ \\
\hline Research & $\begin{array}{l}\text { Research activities, study opportunities research programs } \\
\text { compiling, group, gathering, text magazine research plans... }\end{array}$ \\
\hline Satisfaction & $\begin{array}{l}\text { Management, scientific board and learners satisfaction with all } \\
\text { educational operational remedial hygienic and research aspects. }\end{array}$ \\
\hline
\end{tabular}

Table 4. SWOTs at educational group

O Health Care, research and educational validity of university

T Powerful Scientific board retirement

S Scientific board members, experienced and powerful experts, graduates W Scientific board welfare, modern Technology

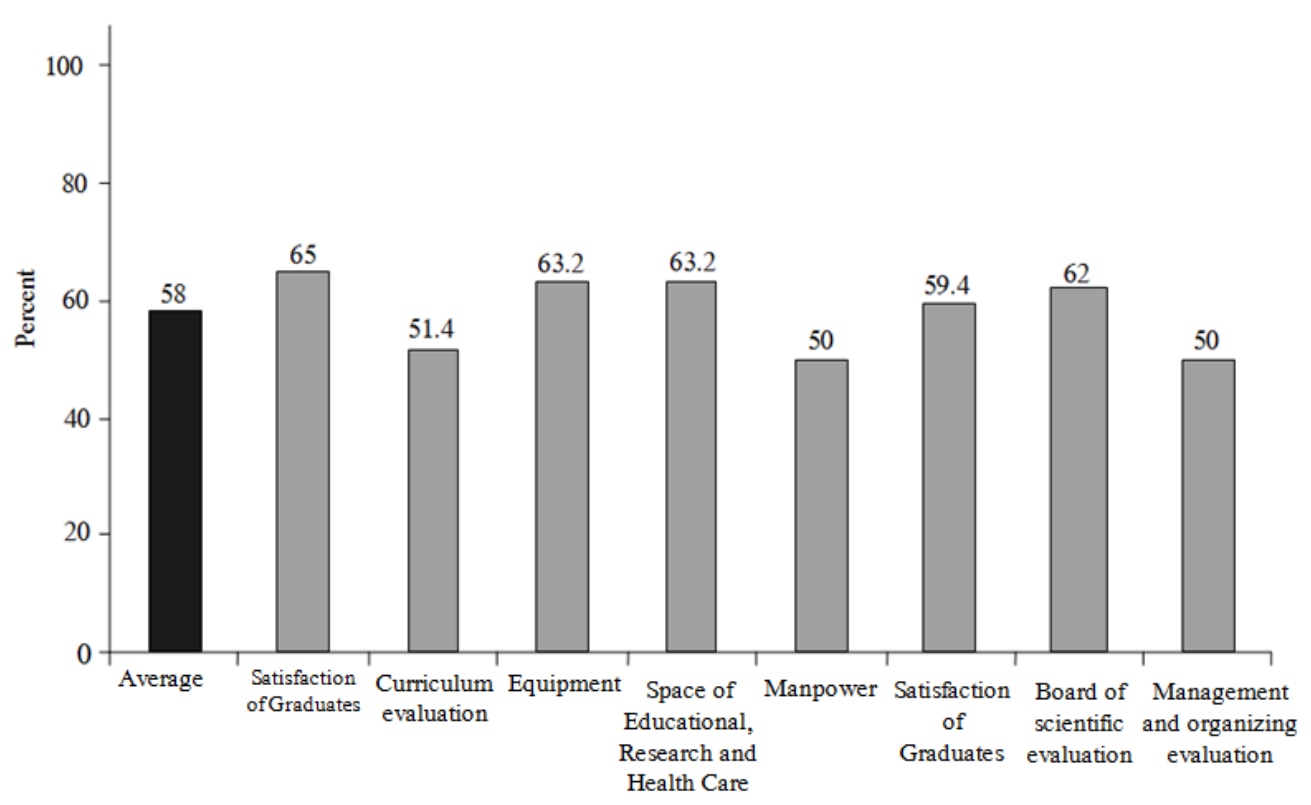

Evaluated factor

Fig. 1. Result of internal evaluation in Dept. of Biochemistry, Tehran University of Medical Sciences 


\section{DISCUSSION}

Educational evaluation is an essential and inseparable component of any organizational functions particularly the organizations such as medical education, remedy and hygiene which is Para medicine coordinator planner and operator as well as variable ranger of remedial and hygienic services in the country (Farzianpour et al., 2010b). It is a process, which deals with collecting data and judging about educational activity promotion (Farzianpour et al., 2010b; 2010c; 2011b; 2011c). Given some principles related to educational measurement and data collecting it could be well understand (Farzianpour et al., 2013b).

The results of the research showed that general average of and investigating sections were $\% 58$ as a desirable research work. Therefore, concluded that function of the educational management in that group was directly in line with evaluation process.

Previous studies in educational evaluation showed average of the function of educational evaluation in basic sciences groups and clinical groups were respectively 76.4 and $86.6 \%$ while grand average of the function of clinical groups and basic sciences groups was $80.5 \%$ (Farzianpour et al., 2013b; 2013c).

Rabbani et al. (2006) showed general average of the function of internal evaluation in Department of pediatrics faculty of medicine were respectively $\% 53.3$ in 2003 and \%75.3 in 2004.

In university educational system, it is possible to use educational evaluation in electing students, scientific board and curriculum and in general the other educational system inputs in addition, it supervises on system process performing and finally using evaluation directs outputs and system consequences optimally (Farzianpour et al., 2011d).

\section{CONCLUSION}

So it is necessary that medical education system structure in our country meets some educational quality and is changed due to existed shortages in educational programs and for meeting society needs.

One of the methods, which can be helpful in identifying strengths and weaknesses in an educational system, is educational evaluation.

Occupational capabilities and graduates efficiency in medical sciences fields depend on the level of achieving objectives in educational programs in order to present remedial, hygienic services, research and educational programs, for promotion of individual and society health level and if educational programs haven't developed and performed correctly, it can cause irreparable damages and economic, cultural and social serious effects on individual and graduates as well as university management and the validity (Farzianpour et al., 2013c).

On the other hand given government wide investment on human resources, financial and physical sources to develop medical education centers it seems necessary to evaluate different aspects of educational programs in medical groups.

So it is necessary to equip the management with control and supervision tools according to educational programs. If educational management has an effective and helpful system for evaluation then it will have an active and dynamic nature.

On the other hand, identifying and analyzing problems and issues in educational system can be considered an important step to improve university educational system and consequently being ready to perform remedial, hygienic and medical development programs in the country (Farzianpour et al., 2013a).

\section{ACKNOWLEDGEMENT}

The authors are grateful to Scientific Boards of Biochemistry, Tehran university of Medical Sciences, Iran, for their helpful assistance.

\subsection{Funding Information}

This study was funded by Educational Development Center (EDC), Tehran University of Medical Sciences, Tehran, Iran.

\subsection{Author's Contributions}

Fereshteh Farzianpour: Wrote the manuscript, conceived the original idea and performed the data analyses.

Mohamad Ansari: Contributed significantly to the interpretation of the results.

Shadi Hosseini: Performed data analyses.

\subsection{Ethics}

This study was approved by the Ethical Committee of Tehran University of Medical Sciences (TUMS). About the nature and purpose of the study was explained to the participants.

\section{REFERENCES}

Farzianpour, F., A.H. Emami, F. Davari-Tanha, S. Hosseini and A.R. Farzanehnejad, 2010a. Educational programs' quality assessment based on graduates' comments. Iranian Red Crescent Med. J., 12: 302-307. 
Farzianpour, F., H. Dargahi, N. Eynolahi and S. Aghababa, 2010b. Internal evaluation in department of health care management in faculty of allied medical sciences Tehran University of Medical Sciences. Health Inform. Manage., 7: 353-360.

Farzianpour, F, A.H. Emami, F. Davari-Tanha, S. Hosseini and A.R. Farzanehnejad, 2010c. Educational programs' quality assessment based on graduates' comments. IRCMJ, 12: 302-307.

Farzianpour, F., H. Dargahi, S. Hosseini, S.S. Hosseini and S. Hosseini, 2011a. Program evaluation of health care management: Is it adjusted for students needs? Am. J. Econ. Bus. Admin., 3: 420-424. DOI: 10.3844/ajebasp.2011.420.424

Farzianpour, F., S. Aghababa, B. Delgoshaei and M. Haghgoo, 2011b. Performance evaluation a teaching hospital affiliated to Tehran university of medical sciences based on baldrige excellence model. Am. J. Econ. Bus. Admin., 3: 272-276. DOI: 10.3844/ajebasp.2011.272.276

Farzianpour, F., A. Rahimi Fouroshani, H. Kamjoo and S.S.H. Hosseini, 2011c. Organizational Citizenship Behavior (OCB) among the managers of teaching hospitals. Am. J. Econ. Bus. Admin., 3: 534-542. DOI: 10.3844/ajebasp.2011.534.542

Farzianpour, F., R. Roholah Askari, A. Torabipoor Hamedani, G.H. Khorshidi and S. Amirifar, 2011d. Accreditation of emergency department at a Teaching Hospital in Tehran University of Medical Sciences in 2010. Am. J. Econ. Bus. Admin., 3: 498-505.

DOI: 10.3844 /ajebasp.2011.498.505

Farzianpour, F., S.H. Hosseini, A.B. Mirsepasi, H. Honary and S. Hosseini, 2013a. Internal evaluation of the department environment $\mathrm{Al}$ health science and engineering. Am. J. Applied Sci., 10: 58-63.

DOI: 10.3844 /ajassp.2013.58.63

Farzianpour, F., S.M. Hosseini, S.S.H. Hosseini, E. Movahed Kor and M. Amerzadeh, 2013b. The relationship between nursing managers' self-reliance and patients, satisfaction in hospitals affiliated to Tehran University of Medical Sciences (TUMS). Payavars Salamat J., 6: 330-341.
Farzianpour, F., S. Geray, A. Rahimi Foroushan, M. Arab and S.H. Hosseini, 2013c. Evaluating the average access to care and continuity of care patients in Tehran teaching hospitals. Health, 5: 2110-2115. DOI: $10.4236 /$ health.2013.512288

Farzianpour, F., S.H. Hosseini, S. Salmani Arani and A.H. Bakhtiari, 2014a. Evaluation of international standards of Patient and Family Rights (PFR) from chief nurses' point of view in hospitals of Iran. Pensee J., 76: 372-382.

Farzianpour, F., S. Alirezaei, A. Rahimi Foroushani and E. Kalantari, 2014b. Evaluation of Care Of Patient (COP) standards in selected hospitals of Tehran University of Medical Sciences. Pensee J., 76: 179-86.

Farzianpour, F., E. Kalantari, A. Rahimi Foroushani and S. Alirezaei, 2014c. Assessment of Patient (AOP) standards in Teaching hospitals in Iran. Pensee J., 5: 119-124.

Farzianpour, F., S.H. Hosseini, S. Mortezagholi and K. Bamdad Mehrbany, 2014d. Accreditation of Patient Family Education (PFE) in theTeaching Hospitals of Tehran University of Medical Sciences from the Nurses view. Penssee J., 76: 182-193.

Farzianpour, F., A. Rahimi Fouroshani, S. Beyzaiee and S. Hosseini, 2012. Evaluation of the selfesteem managers in clinical wards of hospitals affiliated to Tehran University of Medical Sciences. World Appl. Sci. J., 16: 686-692.

Farzianpour, F., A.H. Emami and M.R. Eshraghian, 2009. The satisfaction of medical practitioners from continuing medical education program of Tehran University of Medical Sciences. Iranian Red. Crescent Med. J., 11: 371-376.

Rabbani, A., F. Farzianpour, G. Zamani, A. Zeinaloo and H. Shajari et al., 2006. Internal evaluation in department of pediatrics faculty of medicine, Tehran University of Medical Sciences. Iranian J. Pediatrics, 16: 301-307. 